\title{
Aa. Vv., Confrontations Politics and Aesthetics in Nineteenth-Century France
}

\section{Emanuele Kanceff}

\section{Q OpenEdition}

12 Journals

\section{Edizione digitale}

URL: http://journals.openedition.org/studifrancesi/30678

DOI: 10.4000/studifrancesi.30678

ISSN: 2421-5856

\section{Editore}

Rosenberg \& Sellier

\section{Edizione cartacea}

Data di pubblicazione: 1 avril 2006

Paginazione: 188-189

ISSN: 0039-2944

\section{Notizia bibliografica digitale}

Emanuele Kanceff, «Aa. VV., Confrontations Politics and Aesthetics in Nineteenth-Century France», Studi Francesi [Online], 148 (XLX | I) | 2006, online dal 30 novembre 2015, consultato il 18 avril 2021. URL: http://journals.openedition.org/studifrancesi/30678; DOI: https://doi.org/10.4000/studifrancesi. 30678

Questo documento è stato generato automaticamente il 18 avril 2021.

\section{(c)}

Studi Francesi è distribuita con Licenza Creative Commons Attribuzione - Non commerciale - Non opere derivate 4.0 Internazionale. 


\title{
Aa. Vv., Confrontations Politics and Aesthetics in Nineteenth-Century France
}

\author{
Emanuele Kanceff
}

\section{NOTIZIA}

AA. VV., Confrontations Politics and Aesthetics in Nineteenth-Century France. Selected Proceedings of the Twenty-Fourth Annual Colloquium in Nineteenth-Century French Studies, Amsterdam-Atlanta, Rodopi, 2001 (“Faux titre", 197), pp. 312.

Dal congresso omonimo svoltosi alla Pennsylvania State University è nata questa grossa silloge, frutto di un confronto e di una collaborazione interdisciplinari tra letterati, storici e storici dell'arte, riuniti a riflettere con il pretesto del centenario di un evento di prima importanza nella civiltà francese, l'Affaire Dreyfus, cui, in realtà, è dedicata soltanto la terza ed ultima parte del folto e polimorfo volume. Informiamo il lettore, a difetto di una analisi dettagliata dei rispettivi studi, sul contenuto dei saggi qui raccolti:

I. Negotiating Texts

T.J. FARRANT (Oxford University), Balzac, Satire, and Subversion: The Private Life of the

Avant-propos to La Comédie humaine

Anne FRÉMIOT (University of Leeds) Crime et contamination dans 'Le Dessous de cartes d'une partie de whist' de Barbey d'Aurevilly Philippe MET (University of Pennsylvania) Fantastique, mystification et traduction dans La Guzla de Mérimée Armine KOTIN MORTIMER (University of Illinois at Urbana-Champaign) Secrets of Literature, Resistance to Meaning Aline MURA-BRUNEL (Université de Pau) Le scandale du non-dit: Balzac et Stendhal

7 Timothy RASER (University of Georgia) The Glory of the Critic: Proust's Preface to La Bible d'Amiens Michael J. TILBY (Cambridge University) "Opposition and its Literary Expression in the Late Restoration: A ‘Self-Conscious Model”. 
II. Violence, Defiance, Audaces

Owen HEATHCOTE (University of Bradford) Verbal Hygiene for Oscar: The Expression and Containment of Violence in Balzac's Un début dans la vie

Garrett R. Heysel (Lycoming College) Audacious Modes and Spectacular Models: Fashion in Jean Lorrain

David A. POWELL (Hoftstra University) 'La Pénultième', or the Next-to-Last What? A Musical Approach to Mallarmés 'Démon' -

Debrati SANYAL (University of California, Berkeley) The Object of Poetry: Commodity and Critique in BaudelaireJuliet A. SIMPSON (Buckinghamshire University College) Defiant Acts: The Théâtre d'Art, Décor, and the Radical Symbolist 'Total Work

Gayle ZACHMANN (University of Florida) Offensive Moves in Mallarmé: Dancing with des astres,

III. Politics and Polemics

Eric CAHM (Université de Tours) Moderate Anti-Dreyfusism: The Forgotten Ideology of France's Republican Elite in 1898

Vincent DUCLERT (Université de Paris X and Ecole des Hautes Etudes en Sciences Sociales) Le procès Zola en 1898: «accomplissement de 'J' Accuse... !»

Lucienne FRAPPIER-MAZUR (University of Pennsylvania) Le Discours épique et révolutionnaire dans I.N.R.I. de Léon Cladel

Susan HINER (Vassar College) Paris Pastoral: Re-Figuring Anarchy in Zola's Fin de Siècle'

Leonard R. Koos (Mary Washington University) Making Angels: Abortion Literature in Turnof-the-Century France

20 Jean-Yves MOLLIER (Université de Versailles Saint Quentin-en-Yvelines) La propagande dreyfusarde et antidreyfusarde en France de 1894 à 1900

Michelle PERROT (Université de Paris VII) La Fronde des femmes au temps de l'Affaire Dreyfus

Marvin N. Richards (John Carroll University) 1898: Poetry on Strike, Prose in the Papers. 